\title{
Polifenol Buah Tin (Ficus carica Linn) Menghambat Peningkatan Kadar MCP-1 pada Tikus dengan Diet Tinggi Lemak
}

\section{Polyphenols of Ficus carica Linn Inhibit Elevation of MCP-1 Level of Mice with High Fat Diet}

\author{
Noorma Lukitasari $i^{1}$, Retty Ratnawati ${ }^{2}$, Diana Lyrawati ${ }^{3 *}$ \\ ${ }^{1}$ Program Studi Pendidikan Dokter Fakultas Kedokteran Universitas Brawijaya Malang \\ ${ }^{2}$ Laboratorium Ilmu Faal Fakultas Kedokteran Universitas Brawijaya Malang \\ ${ }^{3}$ Laboratorium Farmasi Fakultas Kedokteran Universitas Brawijaya Malang
}

\begin{abstract}
ABSTRAK
Diantara beberapa jalur patogenesa terjadinya aterosklerosis, salah satu mekanismenya disebabkan karena stres oksidatif yang disebabkan ketidakseimbangan antara oksidan dan antioksidan. Buah tin (Ficus carica Linn) mengandung polifenol yang berfungsi sebagai antioksidan. Penelitian ini bertujuan untuk mengetahui apakah pemberian polifenol buah tin dapat mencegah aterosklerosis melalui penghambatan peningkatan kadar MCP-1 serum. Penelitian menggunakan desain Post test only, dimana 25 ekor sampel tikus galur Wistar jantan dibagi dalam 5 kelompok dan diberi perlakuan selama 65 hari. Kelompok 1-5 merupakan secara berurutan merupakan kelompok kontrol negatif (diet normal), kontrol positif (diet tinggi lemak), dosis A (diet tinggi lemak+polifenol buah tin 4,5 mg/hari), dosis B (diet tinggi lemak + polifenol buah tin 9 $\mathrm{mg} /$ hari) dan dosis C (diet tinggi lemak + polifenol buah tin $18 \mathrm{mg} / \mathrm{hari}$ ). Hasil penelitian menunjukkan bahwa kadar MCP1 serum pada kelompok kontrol positif meningkat sebesar 1,21\% dibanding kelompok kontrol negatif. Pemberian polifenol buah tin pada dosis $9 \mathrm{mg} /$ hari menurunkan kadar MCP-1 sebesar 0,88\% dibanding dengan kelompok yang diberi diet tinggi lemak $(p=0,000)$, dan pada dosis $18 \mathrm{mg} /$ hari kadar MCP-1 sudah kembali normal. Dapat disimpulkan bahwa pemberian polifenol buah tin mampu menghambat peningkatan kadar MCP-1 serum tikus Wistar yang diberi diet tinggi lemak secara bermakna, dengan hasil maksimal pada dosis $18 \mathrm{mg} /$ hari.
\end{abstract}

Kata Kunci: Aterosklerosis, ficus carica, MCP-1 serum, polifenol

\section{ABSTRACT}

One of atherosclerosis pathogenesis was due to oxidative stress caused by an imbalance between oxidant and antioxidant. tin fruit (Ficus carica Linn) contain polyphenol which functioned as antioxidant. This study aimed to determine whether polyphenol of tin fruit could prevent atherosclerosis through elevated serum of MCP-1 inhibition. This research design was using post test only, which 25 male rats wistar strain devided into 5 groups and treated for 65 days. Group 1-5 respectively are negative control group (normal diet), positive control (high fat diet), A dose (high fat diet + tin fruit polyphenol $4,5 \mathrm{mg} /$ day), B dose (high fat diet + tin fruit polyphenol 9mg/day) and C dose (high fat diet + tin fruit polyphenol 18mg/day). Result showed the increasing of MCP-1 serum level in positive control group as 1,21\% compare to negative control one. Provision of $9 \mathrm{mg} /$ day tin fruit polyphenol lowered MCP-1 level serum as $0,88 \%$ compare to positive control goup ( $p=0,000)$, mean while on the dose of $18 \mathrm{mg} /$ day could normalized the level of MCP-1 serum. It can be concluded that polyphenol of tin fruit able to inhibit the elevation of MCP-1 serum of male rat Wistar strain fed by high fat diet significantly, with the maximum dose of $18 \mathrm{mg} /$ day.

Keywords: Atherosclerosis, ficus carica, MCP-1 serum, polyphenols

Jurnal Kedokteran Brawijaya, Vol. 28, No. 1. Februari 2014; Korespondensi: Diana Lyrawati. Laboratorium Farmasi Fakultas Kedokteran Universitas Brawijaya Malang, Jl. Veteran Malang Tel. (0341) 566117Email:eldi_7_98@yahoo.com 


\section{PENDAHULUAN}

Penyakit kardiovaskular merupakan penyebab utama kecacatan dan kematian dini (premature death) di seluruh dunia. Penyebab utama penyakit kardiovaskuler adalah aterosklerosis, yang berkembang selama beberapa tahun, dan terus berlanjut lalu muncul, biasanya pada usia setengah tua (middle age) atau pria dan wanita tua (1-2). Aterosklerosis merupakan salah satu bentuk penyumbatan pada arteri yang dapat disebabkan oleh berbagai faktor, antara lain meningkatnya radikal bebas, disfungsi endotel (3), dan proses inflamasi kronis (4) dengan patogenesis melibatkan kolesterol, bahan lipoid, dan lipofag. Hiperkolesterolemia seringkali mengawali patogenesis aterosklerosis, yang dapat terjadi perlahanlahan mulai usia 10 tahun (2). Selanjutnya yang akan terjadi adalah melekatnya sel-sel mononuklear di dinding arteri, yang dipicu oleh berbagai kemoatraktan antara lain LDL teroksidasi, lipoprotein (a), sitokin (Tumor Necrosizing Factor-alpha (TNF- $\alpha$ ), interleukin-1 (IL-1), MCP-1 (Monocyte Chemoattractant Protein-1)), dan kolagen serta elastin yang terdegradasi, hingga pada tahap kronis dapat menyebabkan timbunan plak aterosklerosis di dinding pembuluh darah (5).

Monocyte Chemoattractant Protein-1 adalah anggota dari sekelompok kemokin grup, chemokine (C-C motif-ligand 2 atau juga biasa disebut CCL2, yang dihasilkan oleh berbagai macam sel termasuk diantaranya monosit, limfosit, sel-sel endotel dan fibroblas setelah distimulasi oleh berbagai mediator inflamasi. MCP-1 berperan sebagai kemoatraktan yang poten dan diyakini berperan penting dalam respon inflamasi pada monosit darah, makrofag jaringan, dan sel-sel pembunuh alami (natural killer cell/NK cell) (6). Penghambatan aktivitas MCP-1 dapat menekan proses inflamasi pada artritis karena inflamasi, sedangkan ekspresi berlebihan dapat meningkatkan recruitment monosit dan limfosit secara in vivo.

Selain proses inflamasi, meningkatnya radikal bebas juga turut berperan pada patogenesis aterosklerosis. Meningkatnya radikal bebas pada jaringan endotel seringkali disebabkan oleh ketidakseimbangan aktivitas oksidasi dan antioksidan yang diakibatkan oleh hiperlipidemia. Peningkatan radikal bebas ini dapat menimbulkan kerusakan jaringan, yang dapat menginduksi sitokin-sitokin pro-inflamasi (3). Seiring dengan meningkatnya radikal bebas pada jaringan, maka kebutuhan akan antioksidan juga meningkat. Salah satu senyawa yang bersifat sebagai antioksidan yang terdapat pada buah-buahan adalah senyawa fenol. Banyak bukti mengenai efek menguntungkan dari antioksidan fenol (termasuk diantaranya monofenol dan polifenol) terhadap penyakit jantung dan kanker (7). Banyak penelitian yang menghubungkan antara polifenol pada tumbuhan terhadap patogenesis aterosklerosis. Antioksidan dapat menjadi strategi terapi untuk pengobatan aterosklerosis dengan mengurangi adhesi macrophage foam-cell dan penyebarannya di intima (8).

Antioksidan terdapat dalam bermacam tumbuhan, salah satunya pada buah tin (Ficus carica Linn). Buah tin (Ficus carica Linn) memiliki konsentrasi polifenol tertinggi, yaitu sebesar 1,090-1,110 mg/100 g buah segar, diantara makanan dan minuman yang biasa di konsumsi (9). Kandungan fenol pada buah tin yang dikeringkan dapat meningkatkan lipoprotein di plasma dan memproteksi terhadap oksidasi. Setelah mengkonsumsi buah tin yang dikeringkan, kapasitas antioksidan pada plasma meningkat secara bermakna (7). Ekstrak basah dari buah tin (dried fruit) dapat digunakan sebagai penghambat radikal bebas dan sebagai antioksidan yang utama. PS (crude hot water-soluble polysaccharide of Ficus carica fruit) dapat digunakan sebagai skavenger superoksida (10). Pada penelitian lain diungkapkan bahwa buah tin memiliki kemampuan antioksidan primer ketika dibandingkan dengan bawang, labu, dan timun (11).

Diperlukan penelitian lebih lanjut untuk mengetahui pengaruh spesifik polifenol buah tin terhadap peran MCP1 dalam patogenesis aterosklerosis. Penelitian ini dirancang untuk mengetahui pengaruh polifenol pada buah tin (Ficus carica Linn) terhadap kadar MCP-1 (Monocyte Chemoattractant Protein-1) pada serum tikus putih galur Wistar (Rattus norvegicus $L$ ) yang diberi diet tinggi lemak. Diharapkan penelitian ini dapat memperkenalkan buah tin sebagai alternatif obat herbal untuk mencegah aterosklerosis, juga sebagai variasi konsumsi buah di Indonesia.

\section{METODE}

\section{Desain Penelitian}

Penelitian ini adalah penelitian eksperimental laboratorik dengan menggunakan desain penelitian post test control group design (12). Pemilihan subjek penelitian untuk pengelompokan dan pemberian perlakuan menggunakan Rancangan Acak Lengkap (RAL). Rancangan eksperimental yang digunakan adalah rancangan eksperimen sederhana, subyek dibagi menjadi 5 kelompok secara random. Tiap kelompok terdiri dari 5 tikus. Kelompok 1 adalah tikus dengan diet normal (kontrol negatif), kelompok 2 adalah tikus diberi diet tinggi lemak (kontrol positif), sedangkan kelompok 3 hingga 5 diberi diet tinggi lemak dan polifenol buah tin dengan dosis per oral masing-masing sebesar 4,5 $\mathrm{mg} /$ hari; $9 \mathrm{mg} /$ hari; dan $18 \mathrm{mg} /$ hari. Polifenol diberikan dengan cara disonde sekali setiap hari. Dilakukan pembedahan pada tikus, dan diambil darah dari jantung sebagai sampel pemeriksaan kadar MCP-1.

\section{Pembuatan Pakan Tikus}

Bahan pakan normal terdiri dari Comfeed PARS 66,67\% (dengan kandungan air $12 \%$, protein $11 \%$, lemak $4 \%$, serat $7 \%$, abu $8 \%$, Ca $1,1 \%$, fosfor $0,9 \%$, antibiotik coccidiostat 53\%) dan air 33,33\%. Diet tinggi lemak terdiri dari pakan babi $50 \%$, tepung terigu $25 \%$, kolesterol $2 \%$, asam kolat $0,2 \%$, minyak babi $5 \%$, dan air $17,8 \%$ (13).

\section{Pembuatan Ekstrak Polifenol Buah Tin}

Sebanyak 600 gram buah tin kering digiling sampai didapatkan gilingan buah sebanyak 580 gram. Dilakukan sonikasi dengan pelarut metanol $3 \times 1$ jam kemudian disaring dan diuapkan pelarutnya. Dari proses tersebut didapatkan 216 gram ampas kering yang tidak terpakai dan $250 \mathrm{ml}$ berupa ekstrak kasar. Ekstrak kasar ini ditambahkan 1 liter air dan selanjutnya dilakukan ekstraksi dengan nheksana. Hasil ekstraksi berupa 1,76 gram ekstrak nheksana dan fasa air. Fasa air inilah yang akan berguna untuk penelitian. Fasa air pertama selanjutnya dilakukan ekstraksi kembali dengan etil asetat dan didapatkan 3 gram ekstrak etil asetat dan fasa air kedua. Fasa air kedua di ekstraksi lagi dengan n-butanol, dan didapatkan hasil 
berupa fasa air ketiga dan 21 gram ekstrak butanol (14). Ekstrak butanol ini diencerkan dengan air lalu dibagi sesuai dosis yang dibutuhkan untuk disondekan ke subjek penelitian sesuai kelompoknya. Pemberian polifenol buah tin dilakukan selama 65 hari.

\section{Penentuan Dosis Polifenol Buah Tin}

Dosis polifenol buah tin yang digunakan pada penelitian ini ditentukan berdasarkan rujukan yang menyatakan bahwa konsumsi total fenol yang dianjurkan pada manusia adalah $>500 \mathrm{mg} /$ hari (15). Berdasarkan Tabel Perbandingan Luas Permukaan Hewan Coba, konversi dosis polifenol tikus terhadap manusia adalah sebagai berikut: $500 \mathrm{mg} /$ hari $\times 0,018=9 \mathrm{mg} /$ hari $(15)$. Variasi pemberian dosis didasarkan pada deret ukur $(1 / 2 n, n$, dan $2 \mathrm{n})$ yaitu: dosis $4,5 \mathrm{mg} /$ hari; $9 \mathrm{mg} /$ hari; dan $18 \mathrm{mg} /$ hari (15).

\section{Pengukuran Kadar MCP-1 Serum}

Pemeriksaan kadar MCP-1 dilakukan menggunakan ELISA kit sesuai manual kit (16). Antibodi primer yang digunakan adalah Anti MCP-1 (RayBioTech) dan antibodi sekunder Antirabbit IgG Biotin Conjugated (RayBioTech) dengan pengenceran 1:1000, dan deteksi dilakukan dengan bantuan reaksi oksidasi horse radish peroksidase (SA-HRP 1:1000) dan Sureblue TMB. Absorban larutan diukur pada $\lambda 450 \mathrm{~nm}$ dengan ELISA Reader (16).

\section{Analisis Data}

Analisis statistik menggunakan SPSS 17.0, uji KolmogorovSmirrnov untuk normalitas, uji homogenitas sampel, dan one way ANOVA serta uji post-hoc untuk mengetahui perbedaan perlakuan yang diberikan. Uji statistik dilakukan pada derajat kepercayaan $95 \%$ dengan $\alpha=0,05$. Hasil uji statistik dinyatakan bermakna bila $p<0,05$.

\section{HASIL}

Hasil uji Kolmogorov-Smirnov menunjukkan bahwa distribusi data normal $(p=0,551)$. Uji homogenitas varian, menunjukkan data memiliki varians homogen $(p=0,440)$. Uji one way ANOVA menunjukkan terdapat perbedaanrerata kadar MCP-1 serum secara bermakna pada masing-masing kelompok $(p=0,000)$.

Pada pemberian polifenol dengan berbagai konsentrasi menunjukkan adanya perbedaan pada kadar MCP-1 serum. Rerata kadar MCP-1 serum pada tikus yang diberi diet tinggi lemak tanpa penambahan polifenol (Kontrol positif) menunjukkan nilai paling tinggi $(655,560 \mathrm{ng} / \mathrm{mL})$ lalu menurun secara berurutan, seiring dengan meningkatnya dosis yang diberikan pada kelompok perlakuan, yaitu $627,360 \mathrm{ng} / \mathrm{mL}$ pada kelompok dengan dosis terkecil (Dosis A 4,5 mg/hari), 576,360 ng/mL pada kelompok dosis kedua (Dosis B $9 \mathrm{mg} /$ hari), dan yang paling rendah yaitu $525,760 \mathrm{ng} / \mathrm{mL}$ pada kelompok dosis terbesar (Dosis C $18 \mathrm{mg} /$ hari). Rerata kadar MCP-1 kelompok yang diberi diet normal sebesar 540,160 ng/mL.

Analisis LSD (Least Significant Difference) dalam uji posthoc tampak bahwa terdapat peningkatan kadar MCP-1 yang berbeda secara bermakna antara kelompok kontrol positif dengan kontrol negatif dengan nilai $p=0,000$ (syarat $\mathrm{p}<0,05)$. Ini menandakan bahwa kadar rata-rata MCP-1 pada kelompok kontrol positif mengalami peningkatan yang dihasilkan oleh perlakuan yang dilakukan oleh peneliti selama penelitian berlangsung.

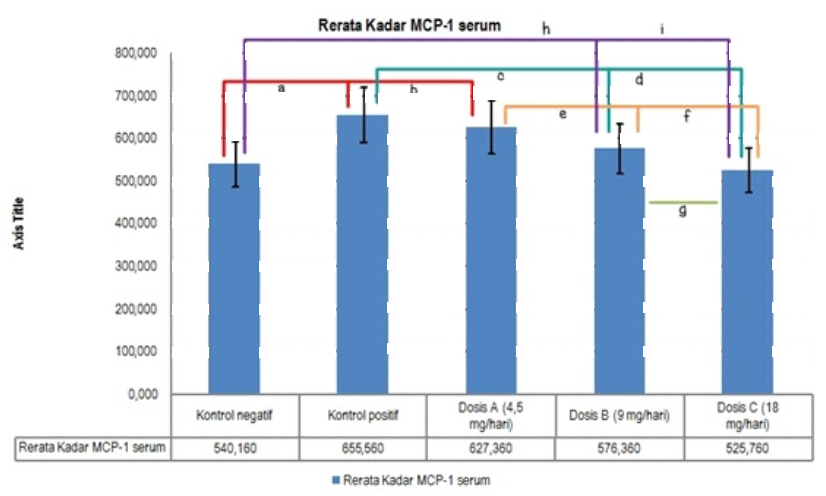

Gambar 1. Perbandingan rata-rata kadar MPC-1 antar masingmasing kelompok perlakuan

Keterangan:

a. Signifikan antara kontrol negatif dan kontrol positif

b. Signifikan antara kontrol negatif dan Dosis $A(p=0,002)$

c. Signifikan antara kontrol positif dan Dosis $B(p=0,003)$

d. Signifikan antara kontrol positif dan Dosis $C(p=0,000)$

e. Signifikan antara Dosis A dan Dosis $B(p=0,045)$

Signifikan antara Dosis A dan Dosis $C(p=0,000)$

Signifikan antara Dosis B dan Dosis $C(p=0,046)$

h. Tidak signifikan antara Kontrol negatif dan Dosis $B(p=0,144)$

i. Tidak signifikan antara Kontrol negatif dan Dosis $C(p=0,552)$

Pada uji post-hoc didapatkan bahwa antara kelompok kontrol positif dan kelompok dosis B terdapat perbedaan yang bermakna $(p=0,003)$, yang artinya adalah pada dosis B $(9 \mathrm{mg} /$ hari) sudah dapat menghambat peningkatan kadar MCP-1. Pada dosis A (4,5 mg/hari) tidak terdapat perbedaan yang bermakna $(p=0,251)$ yang artinya pada dosis A belum bisa menghambat peningkatan kadar MCP1. Antara kelompok kontrol positif dan dosis C (18 mg/hari) juga terdapat perbedaan yang bermakna $(p=0,000)$ yang berarti bahwa kadar polifenol buah tin pada dosis $C$ ini sudah bisa menghambatpeningkatan kadar MCP-1. Antara kontrol negatif dan dosis $B$ maupun dosis $C$ tidak terdapat perbedaan secara bermakna $(p=0,144$ dan $p=0,552)$ yang dapat diartikan bahwa kadar MCP-1 yang terdapat pada kelompok dosis $\mathrm{B}$ dan dosis $\mathrm{C}$ sudah dapat dianggap sama dengan normal walaupun secara angka masih terdapat perbedaan diantara ketiganya. Kadar MCP-1 serum pada kontrol negatif $=540,160 \mathrm{ng} / \mathrm{mL}$; pada dosis $B(9 \mathrm{mg} / \mathrm{hari})=$ $576,360 \mathrm{ng} / \mathrm{mL}$; dan pada dosis $C(18 \mathrm{mg} /$ hari $)=525,760$ $\mathrm{ng} / \mathrm{mL}$.

\section{DISKUSI}

Dari data hasil pengukuran kadar MCP-1 pada serum tikus, dapat diketahui bahwa rata-rata kadar MCP-1 serum yang tertinggi terdapat pada kelompok kontrol positif dan yang terendah terdapat pada kelompok dosis C (18 mg/hari). Penurunan kadar MCP-1 terjadi seiring dengan meningkatnya dosis polifenol yang diberikan pada tikus. Kadar MCP-1 pada dosis B masih diatas dari kadar MCP-1 pada K-, tapi untuk dosis B sudah bisa dipakai untuk menghambat peningkatan kadar MCP-1 karena perbedaan angka ini tidak berbeda secara bermakna. Pada pemberian polifenol buah tindosis C, kadar MCP-1 berada dibawah kadar MCP-1 pada K- yang berarti bahwa dengan dosis C sudah dapat menurunkan kadar MCP-1 sampai dibawah kadar normal.

Kadar MCP-1 serum paling tinggi terdapat pada kelompok kontrol positif, yaitu kelompok yang diberi diet tinggi 
lemak tanpa dosis polifenol buah tin. Hal ini dapat terjadi karena adanya peningkatan jumlah kolesterol akibat komposisi dari makanannya yaitu diet tinggi lemak. Pada diet tinggi lemak ini mengandung banyak asam lemak jenuh yang menyebabkan terbentuknya kolesterol relatif lebih banyak dan digunakan oleh jaringan ekstrahepatik secara lebih lambat daripada partikel yang lebih besar (17). Model aterosklerosis dapat dirancang dengan pemberian diet tinggi lemak dan tinggi kolesterol (diet tinggi lemak) pada tikus Wistar jantan selama 8 minggu (13). Pernyataan tersebut didukung dengan ditemukannya peningkatan jumlah foam cell secara bermakna pada kelompok kontrol positif penelitian polifenol buah tin ini yang menandai berlangsungnya proses aterogenesis. Pada kelompok kontrol positif didapatkan jumlah rata-rata foam cell pada aorta sebanyak 32,6 $\pm 2,793 \mathrm{sel} / 5$ lapang pandang (dihitung per lima lapang pandang, perbesaran 400x), sedangkan pada kelompok kontrol negatif berjumlah $2,4 \pm 0,894$ sel $(p=0,000)(18)$. Patogenesis aterosklerosis merupakan suatu proses kompleks yang hingga saat ini masih belum dimengerti sepenuhnya (19), namun telah diketahui bahwa proses awal aterosklerosis terjadi karena adanya kerusakan endotel vaskular (20).

Kerusakan ini dapat terjadi karena pajanan berbagai jenis iritan terhadap endotel dalam kehidupan sehari-hari. Diantara hal-hal yang dapat menyebabkan iritasi ini adalah kondisi hipertensi, hiperlipidemia, mikroorganisme yang menyerang dinding pembuluh darah, toksin, dan radikal bebas $(19,21)$. Selanjutnya kerusakan lapisan terdalam dinding vaskular ini menstimulasi peningkatan regulasi (up regulation) molekul adhesi endotel, seperti Intracelluler Adhesion Molecule-1 (ICAM-1), Vascular Cell Adhesion Molecule (VCAM), dan Endothelial Leukocyte Adhesion Molecule (ELAM), melalui serangkaian kaskade yang melibatkan sitokin-sitokin inflamasi dan juga menurunkan sekresi zatzat yang mencegah perlekatan pada endotel $(20,21)$. Abnormalitas pembuluh juga akan menstimulasi pelepasan zat-zat kemoatraktan terutama MCP-1, kemudian menarik monosit yang beredar dalam darah menuju lokasi lesi (22). Penarikan monosit menuju ke jaringan sudah terjadi pada area pre lesi, yaitu area yang plak ateromanya belum dapat terlihat, baik secara makroskopis maupun mikroskopis. Peristiwa ini meningkat pada kondisi hiperlipidemia yang diinduksi oleh diet, meskipun induksi diet hanya dalam waktu singkat.

Peran MCP-1 dalam proses terjadinya aterosklerosis adalah ikatannya dengan reseptornya, CCR-2 (CC Receptor-2), akan menginisiasi terbentuknya plak ateroma, yang merupakan lesi awal dari proses aterosklerosis. Sebuah penelitian yang difokuskan pada interaksi monosit dan dinding endotel arteri pulmonal manusia menunjukkan bahwa MCP-1, setelah diekskresikan dan berikatan dengan reseptornya, yaitu

\section{DAFTAR PUSTAKA}

1. World Health Organization.Prevention of Cardiovascular Disease: Guideline for Assessment and Management of Cardiovascular Risk. (Online) 2007. www.who.int/cardiovascular_diseases/guidelines/Pr evention_of_Cardiovascular_Diseases/en [diakses 1 Oktober $201 \overline{2}$ ] reseptor CCR-2 pada permukaan monosit, akan meningkatkan adhesi monosit pada dinding endotel (22).

Diet tinggi lemak yang diberikan akan membuat kondisi hiperlipidemia dan selanjutnya akan terjadi peroksidasi (auto-oksidasi) lemak pada paparan oksigen sehingga dapat menjadi penyebab kanker, penyakit inflamasi, aterosklerosis, dan penuaan. Efek yang mengganggu ini disebabkan oleh radikal bebas yang diproduksi selama proses pembentukan peroksida dari asam lemak, misalnya polyunsaturated fatty acids (asam lemak tak jenuh rantai panjang). Peroksidasi lemak merupakan rangkaian reaksi yang menghasilkan radikal bebas secara terus menerus. Peroksidasi lemak merupakan rangkaian reaksi yang memiliki efek merusak (devastating effect). Untuk mengontrol dan mengurangi peroksidasi lemak, manusia dan alam melibatkan antioksidan (17). Pembentukan radikal bebas menyebabkan lesi pada lapisan endotel, menyebabkan meningkatnya perlekatan, permeabilitas, dan substansi pro-koagulasi (3). Produksi radikal bebas terjadi pada banyak sel di dinding pembuluh darah seperti sel endotel, sel otot polos pembuluh darah, fibroblast, dan makrofag.

Mekanisme polifenol buah tin dalam menghambat peningkatan kadar MCP-1 diperkirakan melalui efek antioksidannya. Antioksidan yang terkandung dalam polifenol buah tin dapat menghambat terjadinya peroksidasi lemak, sehingga radikal bebas yang terbentuk akan berkurang. Proses ini akan mengakibatkan lesi endotel juga makin berkurang jumlahnya, sehingga MCP-1 tidak terstimulasi, maka tidak akan terbentuk plak ateroma yang merupakan inisiasi terjadinya aterosklerosis. Dengan demikian dapat dikatakan bahwa polifenol yang terkandung dalam buah tin dapat menghambat peningkatan kadar MCP-1 pada tikus yang diberi diet tinggi lemak.

Buah tin mengandung beberapa macam zat fenolik, antara lain asam galat; asam klorogenat; asam siringat; (+)katekin; (-)-epikatekin dan rutin (23). Setiap jenis zat tersebut mungkin memiliki potensi yang berbeda dalam menghambat peningkatan MCP-1. Karena pada penelitian ini digunakan isolat polifenol total yang masih merupakan campuran berbagai zat fenolik, maka masih diperlukan penelitian lanjutan untuk mengetahui mana polifenol spesifik yang paling berperan menghambat MCP-1.

Pada penelitian ini, terbukti pemberian diet tinggi lemak atherogenik selama 65 hari dapat meningkatkan kadar MCP-1 serum tikus Wistar secara bermakna. Pemberian polifenol buah tin mampu menghambat peningkatan kadar MCP-1 serum pada diet secara bermakna mulai dosis $9 \mathrm{mg} /$ hari pada tikus, setara dengan $500 \mathrm{mg} /$ hari untuk manusia (15). Pemanfaatan polifenol buah tin sebagai usaha preventif aterosklerosis patut dikembangkan. Penelitian lanjut perlu dilakukan untuk melihat efek terapeutik pada pemakaian jangka panjang, serta efek samping yang mungkin terjadi.

2. Anwar TB. 2004. Dislipidemia sebagai Faktor Risiko Penyakit Jantung Koroner. [Repository]. Universitas Sumatera Utara, Medan. 2004.

3. Napoli C and Lerman LO. 2001. Involvement of Oxidation-Sensitive Mechanisms in the Cardiovascular Effects of Hypercholesterolemia. Mayo Clinical Proceedings. 2004; 76(6): 619-631. 
4. Getz GS and Reardon CA. Nutrition and Cardiovascular Disease. Arteriosclerosis, Thrombosis, and Vascular Biology. 2007; 27: 2499-2506.

5. Ross R. Atherosclerosis-an Inflammatory Disease. The New England Journal of Medicine. 1999; 340: 115126.

6. Gu L, Okada Y, Clinton Sk, et al. Absence of Monocyte Chemoattractant Protein-1 Reduces Atherosclerosis in Low Density Lipoprotein Receptor-Deficient Mice. Molecular Cell. 1998; 2(2): 275-281.

7. Vinson JA, Zubik L, Bose P, Samman N, and Procj J. Dried Fruits: Excellent in Vitro and in Vivo Antioxidants. The Journal of the American College of Nutrition. $2005 ; 24(1)$ : 44-50.

8. Curtiss LK. Reversing Atherosclerosis? The New England Journal of Medicine. 2009; 360: 1144-1146.

9. Vinson JA. The Functional Food Properties of Figs. American Association of Cereal Chemist. 1999; 44(2) 82-87.

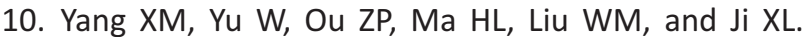
Antioxidant and Immunity Activity of Water Extract and Crude Polysaccharide from Ficus carica L. Fruit. Plant Foods for Human Nutrition. 2009; 64(2): 167-173.

11. Qusti, SY, Ahmed, Abo-khatwa AN, and Lahw MA. Screening of Antioxidant Activity and Phenolic Content of Selected Food Items Cited in The Holy Quran. Journal of Biological Sciences. 2010; 2(1): 40-51.

12. Notoatmojo S. Metodologi Penelitian Kesehatan. Jakarta: Rineka Cipta; 2002; hal. 165-167.

13. Murwani S, Mulyohadi A, Muliartha K.Diet Atherogenik pada Tikus Putih sebagai Model Hewan Aterosklerosis. Jurnal Kedokteran Brawijaya. 2005; 22(1): 6-9.

14. Dewi LP dan Ciptati. Isolasi Senyawa Antioksidan dari Buah Tin (Ficus carica Linn). [Laporan Penelitian].
Tidak Diterbitkan. Institut Teknologi Bandung, Bandung. 2010.

15. Williamson $G$ and Holst B.Dietary Reference Intake (DRI) Value For Dietary Polyphenols: Are We Heading in the Right Direction? British Journal of Nutrition. 2008; 99(Suppl. 3): S55-S58.

16. RayBio.Rat MCP-1 ELISA Kit. User Manual (Revised Mar 1, 2012). (Online) 2012. http://www.funakoshi .co.jp/data/datasheet/RAY/ELR-MCP1-001.pdf [diakses 10 Oktober 2012].

17. Murray RK, Granner DK, and Rodwell VW. Harper's Illustrated Biochemistry. 27th edition. London: McGraw-Hill Companies; 2009.

18. Purborisanti DK. Pengaruh Polifenol Buah Tin (Ficus Carica Linn.) terhadap Pembentukan Foam Cell Pada Aorta Tikus (Rattus Norvegicus L.) Dengan Diet Aterogenik.[Tugas Akhir]. Tidak Diterbitkan. Universitas Brawijaya, Malang. 2012.

19. Price SA and Wilson. Pathophysiology: Clinical Concepts of Disease Processess. 6th Edition. Jakarta: Penerbit Buku Kedokteran EGC; 2006.

20. Guyton AC and Hall JE. Textbook of Medical Physiology. 11th edition. Philadelphia: Elsevier Inc; 2006; p. 840-851.

21. BoyleJJ. Macrophage Activation in Atherosclerosis: Pathogenesis and Pharmacology of Plaque Rupture. Current Vascular Pharmacology. 2005; 3(1): 63-68.

22. Maus U, Henning S, Wenschuh H, Mayer K, Seeger W, and Lohmeyer J. Role of Endothelial MCP-1 in Monocyte Adhesion of Inflammed Human Endothelium Under Physiological Flow. American Journal of Physiology-Heart Circulation Physiology. 2002; 283(6): 2584-2591.

23. Veberic R, Colaric M, and Stampar F. Phenolic acids and Flavonoids of Fig Fruit (Ficus carica L.) in the Northern Mediterranean Region. Food Chemistry. 2008; 1(1): 153-157. 